\title{
An Introduction to Bioactivity of Fucoidan
}

\author{
Merve Tutuncu* and Zekiye Altun \\ Department of Basic Oncology, Turkey \\ *Corresponding author: Merve Tutuncu, Department of Basic Oncology, Turkey
}

\begin{tabular}{|c|c|}
\hline ARTICLE INFO & ABSTRACT \\
\hline Received: 㓞 January 25, 2019 & $\begin{array}{l}\text { Citation: Merve Tutuncu, Zekiye Altun. An Introduction to Bioactivity of Fucoidan. Biomed J Sci \& } \\
\text { Tech Res 14(1)-2019. BJSTR. MS.ID.002480. }\end{array}$ \\
\hline
\end{tabular}

Published: 㓞 February 04, 2019

\section{Fucoidan}

Fucoidan is a polysaccharide, which is derived from brown algae and some marine invertebrates, consisting mainly of L-fucose and sulfate ester groups [1]. Fucoidan is particularly found in the cell wall of marine brown algae. This polysaccharide is named as fucoidin when it is derived from the first marine brown algae. Kylin gave Fucoidin in 1913. However, this name has been changed to fucoidan according to IUPAC rules [2]. Fucoidan related different studies have performed in the literature [1,2]. It has different bioactivities such as anticoagulant, anti-thrombotic, antiinflammatory, antitumoral, immunomodulatory, anti-inflammatory, antioxidant, anti-hepatopathy, anti-uropathy, anti-inflammatory. These activities depend on the source of fucoidan samples taken from different species [1,2]. In addition, fucoidan is non-toxic or any adverse effects on the healthy tissues so that it can be used safety. There are many forms of fucoidan but the simplest molecular structure of fucoidan is obtained from Fucus vesiculosus consists mainly of $44.1 \%$ fucose, $26.3 \%$ sulphate and $31.1 \%$ ash and a small proportion of aminoglucose $[3,4]$.

\section{Bioactivity of Fucoidan}

Anticancer effect of fucoidan on various cancer cells has been showed thus far. The researchers have showed that its' anticancer effect induced by inhibiting angiogenesis, metastasis and invasion and by cell accumulation in sub G0 / G1 phase [5-8]. In a study, examining about the effect of fucoidan on human metastatic PC-3 prostate cancer cells showed that fucoidan increased the levels of p21 / WAF1 / CIP1 in cells and suppressed the E2F transcription factor. In another research related to effect of Fucoidan on Burkitt's lymphoma cells have also been showed to suppress metalloproteinase-9 secretion and migration [9]. Fucoidan induces apoptosis by extrinsic and intrinsic pathways in cancer cells. It is reported that the activation of caspase- 3 due to the permeability of the mitochondrial membrane is reduced [6]. Besides, Fucoidan stimulates ER stress mechanisms by induces Toll-like receptor-4 regulated reactive oxygen species and promotes endoplasmic reticulum stress-mediated apoptosis in lung cancer cell lines and tumors [10]. Consequently, it would be suggested that fucoidan induces apoptosis in cancer cells, but its effect depends upon dose and time. One study has been reported that fucoidan has significantly increased drug efficacy because of synergistic effects with anticancer drugs. Furthermore, the immune response has been shown to increase the activity of T cells and reduce the effect of free oxygen radicals as a protective effect of fucoidan against side effects of chemotherapeutic drugs [9]. Fucoidan coated doxorubicin nanoparticles for the transmission of doxorubicin, shows a significant increase in the cell is also determined in the literature. According to this effect, it is thought to be an important agent in increasing the effectiveness of cancer drugs [11]. Masahide et al. indicated that fucoidan regulated the incidence of fatigue for the period of chemotherapy.

The study outcomes showed that chemotherapy with fucoidan group was endured for a longer period than chemotherapy without fucoidan group. Besides, Fucoidan inhibited toxicity of chemotherapeutic agents. As a result, the survival of patients with fucoidan treatment group was longer than that the patients without fucoidan [12]. Fucoidan is a safely agent both increasing the antitumoral effects of chemotherapeutics beside it has no adverse effects on healthy tissues. Fucoidan has the potential to be a high influence drug without damaging normal tissue and by reducing 
the side effects of anticancer drugs. However, it is still needed to study understanding the mechanism of fucoidan.

\section{References}

1. Li B, Lu F, Wei X, Zhao R (2008) Fukoidan: Structure and Bioactivity. Molecules 13(8): 1671-1695.

2. Pomin VH (2015) Sulfated glycans in inflammation. Eur J Med Chem 92: 353-369.

3. Ahmed AB, Adel M, Karimi P, Peidayesh M (2014) Pharmaceutical, cosmeceutical, and traditional applications of marine carbohydrates. Adv Food Nutr Res 73: 197-220.

4. Han YS, Lee JH, Jung JS, Noh H, Baek MJ, et al. (2015) Fucoidan protects mesenchymal stem cells against oxidative stress and enhances vascular regeneration in a murine hindlimb ischemia model. Int J Cardiol 198: 187-195.

5. Kim EJ, Park SY, Lee JY, Park JHY (2010) Fucoidan present in Brown algea induces apoptosis of human colon cancer cells. BMC Gastroenterol 10: 96.

6. Abudabbus A, Badmus JA, Shalaweh S, Bauer R, Hiss D (207) Effects of Fucoidan and Chemotherapeutic Agent Combinations on Malignant and Non-malignant Breast Cell Lines. Curr Pharm Biotechnol 8(9): 748-757.

ISSN: 2574-1241

DOI: 10.26717.BJSTR.2019.14.002480

Merve Tutuncu. Biomed J Sci \& Tech Res

CC (i) This work is licensed under Creative

Submission Link: https://biomedres.us/submit-manuscript.php
7. Hyun JH, Kim SC, Kang JI, Kim MK, Boo HJ, et al. (2009) Apoptosis inducing activity of fucoidan in HCT-5 colon carcinoma cells. Biol Pharm Bull 32 (10): 760-764.

8. Schneider T, Ehrig K, Liewert I, Alban S (2015) Interference with the CXCL2/CXCR4 axis as potential antitumor strategy: superiority of a sulfated galactofucan from the brown alga Saccharina latissima and fucoidan over heparins. Glycobiology 25(8): 82-24.

9. Jeong YT, Kim YD, Jung YM, Park DC, Lee DS, et al. (2013) Low molecular weight fucoidan improves endoplasmic reticulum stress-reduced insülin sensitivity through AMP-activated protein kinase activation in L6 myotubes and restores lipid homeostasis in a Mouse model of type 2 diabetes. Mol Pharmacol 84(1): 47-57.

10. Hsu H Y, Lin TY, Lu M K, Leng PJ, Tsao SM, et al. (2017) Fucoidan induces Toll-like receptor 4 regulated reactive oxygen species and promotes endoplasmic reticulum stress-mediated apoptosis in lung cancer. Sci Rep 7: 44990 .

11. H Kim, VP Nguyen, P Manivasagan, MJ Jung, SW Kim (2017) Doxorubicinfucoidan-gold nanoparticles composite for dual-chemo-photothermal treatment on eye tumors. Oncotarget 8(69): 113719-113733.

12. Ikeguchi M, Yamato M, Arai Y, Maeta Y, K Ashida, et al. (2000) Fucoidan reduces the toxicity of chemotherapy for patients with unresectable advanced or recurrent colorectal cancer. Oncol Lett 2(2): 39-322.

$\begin{array}{ll}\text { BIOMEDICAL } & \text { Assets of Publishing with us } \\ \text { RESEARCHES } & \text { - Global archiving of articles } \\ & \text { - Immediate, unrestricted online access } \\ & \text { - Rigorous Peer Review Process } \\ & \text { - Authors Retain Copyrights }\end{array}$

